\title{
Validation List no. 104 \\ Validation of publication of new names and new combinations previously effectively published outside the IJSEM
}

Correspondence

Jean Euzéby

email address can be found at www.bacterio.net

\begin{abstract}
The purpose of this announcement is to effect the valid publication of the following new names and new combinations under the procedure described in the Bacteriological Code (1990 Revision). Authors and other individuals wishing to have new names and/or combinations included in future lists should send three copies of the pertinent reprint or photocopies thereof to the IJSEM Editorial Office for confirmation that all of the other requirements for valid publication have been met. It is also a requirement of IJSEM and the ICSP that authors of new species, new subspecies and new combinations provide evidence that types are deposited in two recognized culture collections in two different countries (i.e. documents certifying deposition and availability of type strains). It should be noted that the date of valid publication of these new names and combinations is the date of publication of this list, not the date of the original publication of the names and combinations. The authors of the new names and combinations are as given below, and these authors' names will be included in the author index of the present issue and in the volume author index. Inclusion of a name on these lists validates the publication of the name and thereby makes it available in bacteriological nomenclature. The inclusion of a name on this list is not to be construed as taxonomic acceptance of the taxon to which the name is applied. Indeed, some of these names may, in time, be shown to be synonyms, or the organisms may be transferred to another genus, thus necessitating the creation of a new combination.
\end{abstract}

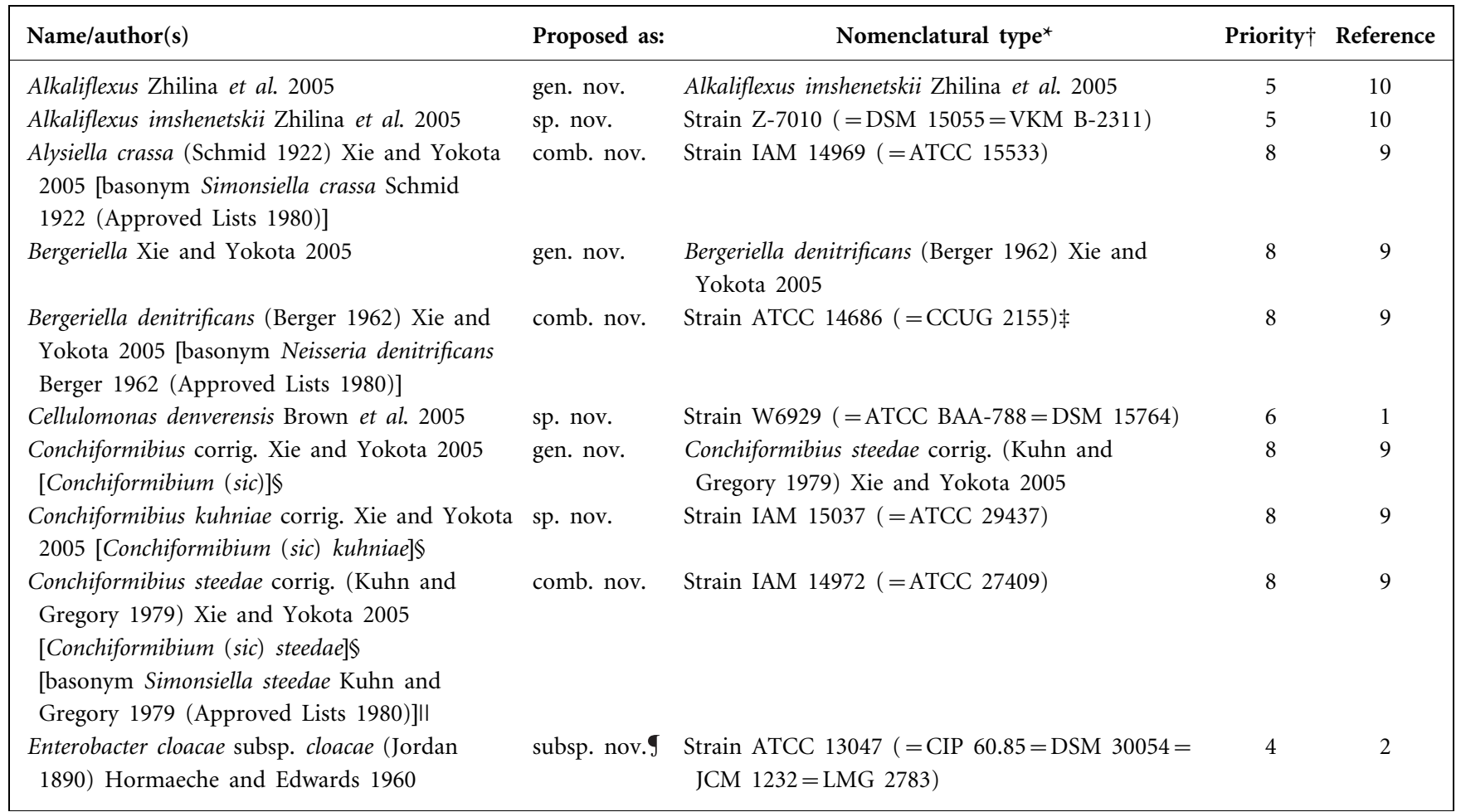


cont.

\begin{tabular}{|c|c|c|c|c|}
\hline Name/author(s) & Proposed as: & Nomenclatural type ${ }^{\star}$ & Priority $\dagger$ & Reference \\
\hline $\begin{array}{l}\text { Enterobacter cloacae subsp. dissolvens (Rosen } \\
\text { 1922) Hoffmann et al. } 2005 \text { [basonym } \\
\text { Erwinia dissolvens (Rosen 1922) Burkholder } \\
1948 \text { (Approved Lists 1980)] }\end{array}$ & comb. nov. & $\begin{array}{l}\text { Strain ATCC } 23373(=\text { CIP } 105586=\text { JCM } 6049= \\
\text { LMG 2683) }\end{array}$ & 4 & 2 \\
\hline Enterobacter radicincitans Kämpfer et al. 2005 & sp. nov. & Strain D5/23 (=DSM $16656=$ CIP 108468) & 3 & 5 \\
\hline Meiothermus timidus Pires et al. 2005 & sp. nov. & Strain SPS-243 $(=$ LMG $22897=$ CIP 108604$)$ & 2 & 7 \\
\hline Nocardia anaemiae Kageyama et al. 2005 & sp. nov. & $\begin{array}{l}\text { Strain IFM } 0323(=\text { NBRC } 100462=\text { JCM } 12396= \\
\text { DSM 44821) }\end{array}$ & 7 & 4 \\
\hline $\begin{array}{l}\text { Thioalkalivibrio thiocyanodenitrificans corrig. } \\
\text { Sorokin et al. } 2005 \text { [Thialkalivibrio (sic) } \\
\text { thiocyanodenitrificans]\# }\end{array}$ & sp. nov. & Strain ArhD $1(=\text { UNIQEM U226=DSM 16954 })^{\star *}$ & 1 & 8 \\
\hline $\begin{array}{l}\text { Wautersia numazuensis corrig. Kageyama et al. } \\
2005 \text { [Wautersia numadzuensis (sic)]†† }\end{array}$ & sp. nov. & Strain TE26 $(=$ NBRC $100056=$ DSM 15562) & 9 & 3 \\
\hline Xenorhabdus budapestensis Lengyel et al. 2005 & sp. nov. & Strain DSM 16342 (=NCIMB 14016) & 10 & 6 \\
\hline Xenorhabdus ehlersii Lengyel et al. 2005 & sp. nov. & Strain DSM 16337 (=NCIMB 14018) & 10 & 6 \\
\hline Xenorhabdus innexi Lengyel et al. 2005 & sp. nov. & Strain DSM 16336 (=NCIMB 14017) & 10 & 6 \\
\hline Xenorhabdus szentirmaii Lengyel et al. 2005 & sp. nov. & Strain DSM 16338 (=NCIMB 14019) & 10 & 6 \\
\hline
\end{tabular}

For references to Validation Lists 1-71, see Int J Syst Bacteriol 49 (1999) 1325. Lists 72-103 were published in Int J Syst Evol Microbiol 50 (2000) 3 , 423, 949, 1415, 1699, 1953; and 51 (2001) 1, 263, 793, 1229, 1619, 1945; and $\mathbf{5 2}$ (2002) 3, 685, 1075, 1437, 1915; and 53 (2003) 1, 373, 627, 935, 1219, 1701; and 54 (2004) 1, 307, 631, 1005, 1425, 1909; and 55 (2005) 1, 547, 983.

*Abbreviations: ATCC, American Type Culture Collection, Manassas, VA, USA; CCUG, Culture Collection, University of Göteborg, Göteborg, Sweden; CIP, Collection of the Institute Pasteur, Paris, France; DSM, DSMZ - Deutsche Sammlung von Mikroorganismen und Zellkulturen, Braunschweig, Germany; IAM, Institute of Molecular and Cellular Biosciences, University of Tokyo, Tokyo, Japan; IFM, Research Center for Pathogenic Fungi and Microbial Toxicoses, Chiba University, Chiba, Japan; JCM, Japan Collection of Microorganisms, RIKEN, Saitama, Japan; LMG, LMG Culture Collection, Universiteit Gent, Gent, Belgium; NBRC, NITE Biological Resource Center, National Institute of Technology and Evaluation, Kisarazu-shi, Chiba Pref., Japan; NCIMB, National Collection of Industrial and Marine Bacteria, Aberdeen, UK; UNIQEM, Unique and Extremophilic Microorganisms Collection of Winogradsky Institute of Microbiology RAS, Moscow, Russia. VKM, All-Union Collection of Microorganisms, Institute of Biochemistry and Physiology of Microorganisms, Russian Academy of Sciences, Pushchino, Moscow Region, Russia. $\dagger$ Priority number assigned according to the date the documentation and request for validation are received.

$¥$ The culture collection accession number NCTC 10295 is also cited in the effective publication, but the authors did not provide a certificate of deposition from this collection.

\$The name of the genus has been corrected on validation. According to Rule 65(2) Conchiformibius corrig. is in the masculine gender. IIIn the effective publication the basonym is erroneously cited as Simonsiella steedae Kuhn and Gregory 1978 (sic) (Approved Lists 1980).

In the effective publication, Enterobacter cloacae subsp. cloacae is erroneously proposed as a new combination.

\#The name of the genus has been corrected on validation.

${ }^{*}$ In the effective publication the type strain UNIQEM U226 is cited as UNIQEM 226. The culture collection accession number DSM 16954 has been provided on request for validation.

$\dagger \dagger$ Epithet has been corrected on validation according to Rule 61 of the Bacteriological Code (1990 Revision).

\section{References}

1. Brown, J. M., Frazier, R. P., Morey, R. E., Steigerwalt, A. G., Pellegrini, G. J., Daneshvar, M. I., Hollis, D. G. \& McNeil, M. M. (2005). Phenotypic and genetic characterization of clinical isolates of CDC coryneform group A-3: proposal of a new species of Cellulomonas, Cellulomonas denverensis sp. nov. J Clin Microbiol 43, 1732-1737.

2. Hoffmann, H., Stindl, S., Ludwig, W., Stumpf, A., Mehlen, A., Heesemann, J., Monget, D., Schleifer, K. H. \& Roggenkamp, A. (2005). Reassignment of Enterobacter dissolvens to Enterobacter cloacae as E. cloacae subspecies dissolvens comb. nov. and emended description of Enterobacter asburiae and Enterobacterkobei. Syst Appl Microbiol 28, 196-205.
3. Kageyama, C., Ohta, T., Hiraoka, K., Suzuki, M., Okamoto, T. \& Ohishi, K. (2005). Chlorinated aliphatic hydrocarboninduced degradation of trichloroethylene in Wautersia numadzuensis sp. nov. Arch Microbiol 183, 56-65.

4. Kageyama, A., Yazawa, K., Nishimura, K. \& Mikami, Y. (2005). Nocardia anaemiae sp. nov. isolated from an immunocompromised patient and the first isolation report of Nocardia vinacea from humans. Jpn J Med Mycol 46, 21-26.

5. Kämpfer, P., Ruppel, S. \& Remus, R. (2005). Enterobacter radicincitans sp. nov., a plant growth promoting species of the family Enterobacteriaceae. Syst Appl Microbiol 28, 213-221.

6. Lengyel, K., Lang, E., Fodor, A., Szállás, E., Schumann, P. \& Stackebrandt, E. (2005). Description of four novel species of Xenorhabdus, family Enterobacteriaceae: Xenorhabdus budapestensis 
sp. nov., Xenorhabdus ehlersii sp. nov., Xenorhabdus innexi sp. nov., and Xenorhabdus szentirmaii sp. nov. Syst Appl Microbiol 28, 115-122.

7. Pires, A. L., Albuquerque, L., Tiago, I., Nobre, M. F., Empadinhas, N., Verissimo, A. \& da Costa, M. S. (2005). Meiothermus timidus sp. nov., a new slightly thermophilic yellow-pigmented species. FEMS Microbiol Lett 245, 39-45.

8. Sorokin, D. Yu., Tourova, T. P., Antipov, A. N., Muyzer, G. \& Kuenen, J. G. (2004). Anaerobic growth of the haloalkaliphilic denitrifying sulfur-oxidizing bacterium Thialkalivibrio thiocyanodenitrificans sp. nov. with thiocyanate. Microbiology 150, 2435-2442.
9. Xie, C.-H. \& Yokota, A. (2005). Phylogenetic analysis of Alysiella and related genera of Neisseriaceae: proposal of Alysiella crassa comb. nov., Conchiformibium steedae gen. nov., comb. nov., Conchiformibium kuhniae sp. nov. and Bergeriella denitrificans gen. nov., comb. nov. J Gen Appl Microbiol 51, $1-10$.

10. Zhilina, T. N., Appel, R., Probian, C., Llobet Brossa, E., Harder, J., Widdel, F. \& Zavarzin, G. A. (2004). Alkaliflexus imshenetskii gen. nov. sp. nov., a new alkaliphilic gliding carbohydratefermenting bacterium with propionate formation from a soda lake. Arch Microbiol 182, 244-253. 